\title{
Nutritional Changes of Sorghum after Popping by a Developed Infrared Assisted Hot Air Popping Machine
}

\author{
P. K. Anjitha ${ }^{1}$, N. Baskaran ${ }^{2}$, N. Venkatachalapathy ${ }^{3}$ and M. Tito Anand* \\ ${ }^{1}$ Department of Workshop and Fabrication Unit, ${ }^{2}$ Department of Food Processing Business \\ Incubation Centre, ${ }^{3}$ Department of Food Engineering, Indian Institute of Food Processing \\ Technology, Thanjavur, Tamilnadu, India \\ *Corresponding author
}

\section{A B S T R A C T}

\begin{tabular}{|l|}
\hline Key w o r d s \\
Popping, Infrared, \\
Sorghum, \\
$\begin{array}{l}\text { Nutritional } \\
\text { composition }\end{array}$ \\
\hline Article Info \\
\hline $\begin{array}{l}\text { Accepted: } \\
\text { 25 December } 2020 \\
\text { Available Online: } \\
\text { 10 January } 2021\end{array}$ \\
\hline
\end{tabular}

\section{Introduction}

Ready to eat snacks are the most important part of the food industry. The development of a healthy snacks that meets the consumer's need and expectation challenging to all food trades. Numerous technologies are used in the manufacturing of snacks (Pardeshi and Chattopadhyay, 2010). Traditional methods are improved and advanced technologies promote the increased production of the food products and improve the texture and taste. The appearance, texture and taste is the key factor when it comes to consumers, The unique quality of the food product appeals to wide variety of people (Kumari et al., 2019). The puffed and popped ready to eat foods has more admirers by virtue of appearance, color, flavor, visual texture, eating qualities, crispiness and convenience.in this era of fast life, rapid urbanization and a health conscious society makes the RTE popped or puffed foods undeniable.

Popped grains are healthy snacks. The intake of whole grain in daily life is suggested by the 
nutritive recommendation of the world strategy of populace. The outer layer of grain and germ as well as whole grain contain fiber, micronutrients and phytochemicals (Raninen et al., 2011) and is an important source of antioxidants (Miller et al., 2000) which makes the WG more beneficial to health. In grain classification sorghum is a nutritious millet that helps in the growth of bones, muscles, skin and enzymes are given by protein. Iron enhances the immune system and the blood's ability to hold oxygen. Vitamin B6 is involved in composing antibodies and enhancing nerve function. Improved blood flow is created by Niacin. Magnesium allows calcium to be absorbed and body temperature regulated. Phosphorus helps form strong bones.

Sorghum (Sorghum bicolor [L.] Moench) is the fifth utmost vital cereal globally in terms of productivity (Wrigley et al., 2004). Sorghum enriched with nutrient which makes the popped sorghum as a nutritious snack. Sorghum is a major millet in the cereal family. It's rich in vitamins and minerals like B vitamins, magnesium, potassium, phosphorus, iron, and zinc. It's as well a great source of fiber, antioxidants, and protein also it is a good resource of bioactive compounds in addition Sorghum is gluten free. The low starch digestibility and protein present in sorghum helps to manage and reduce weight and obesity as well noted that in certain variety are rich in polyphenols such as natural antioxidants and tannins (Dykes \& Rooney., 2006). The unique nutritional properties of sorghum earned a special consideration in production of human food in various form of utilization. Apart from this sorghum is an important ingredient in industrial application for example the increased use of sorghum in production of ethanol and biofuel (Ai et al., 2011). After popping protein digestibility is increased when it comparing with raw sorghum (Llopart \& Drago, 2016). The benefits of sorghum promote to the health of humans. This is why the popped sorghum is considered as a healthy snack. The studies revealed that the compound isolated from the sorghum which has an impact on no communal diseases (Moraiscardoso et al., 2017). The popped sorghum which improves the digestibility, color, aroma, flavor, shelflife and lowers anti-nutritional properties.

Popping is an instantaneous gelatinization of starch and expansion process when the grains are exposed to high temperature for short time. Throughout popping the superheated vapor formed inside the grain by instantaneous heating, the grain is also cooked by the sudden expansion of the endosperm, which breaks the surface epidermis. There are various causes which affecting the popping are season, varietal difference, grain features, moisture content, constituents of grain, physical appearance, type of endosperm, temperature, time and popping method (Mishra et al., 2015). There is various kind of popping or puffing methods are used since years ago. The conventional methods such as dry heat, sand or salt treated puffing, popping in hot oil, gun puffing, hot air popping and microwave heating. (Shukla \& Gour, 2014) reported that sand popping is an oldest technique in this the sand is filled in a pan it heated to a higher temperature the temperature of sand is about to $250{ }^{\circ} \mathrm{C}$ and using a spatula grains are mixed with hot sand. Popping by hot oil there is a slight amount of oil is used. The temperature of the oil varies between $200-220{ }^{\circ} \mathrm{C}$ (Hoke et al., 2005). Another method is popping by treating with salt this also an oldest method had been inherited. In this method the slat also applied during the popping process which enhances the popping process. Next is the gun popping this contain a high pressure chamber or gun because of preheating the grains are introduced into it. Microwave cooking is a modern technique now a days used broadly. 
According to the surveys these methods are time consuming methods or affected the popping quality (Mishra et al., 2014).

In recent times a wide application of IR radiations has been used in food processing industries due to numerous benefits such as uniform temperature, energy-saving, reduction in heating time, decrease in overall product quality loss also it provides high quality and safe and hygienic processed foods. IR is used in numerous food preserving applications such as drying, roasting, pasteurization, baking. cooking, peeling, disinfection, popping, sterilization and blanching. The acceptance of IR is more than conventional methods for the reason that of the pluses (Hebbar et al., 2004). But still people refused to use the infrared processed food items due to the safety problems. The objective of this study is the effect of popping on nutritional properties of the sorghum by using an infrared assisted hot air popping which provides the knowledge about the chemical changes during popping also it compares with the nutritional quality of raw sorghum.

\section{Materials and Methods}

\section{Raw material}

A single commercial variety of sorghum named as nirmal 40 (truthful variety hybrid) was collected from the market and it is washed and dried.

\section{Popping method}

Raw sorghum cleaned and a moisture content of $16 \pm 0.5 \%$ (wb). $10 \mathrm{gm}$ of sample is subjected to a newly developed popping machine by using infrared was adapted for the popping process. Hot air temperature ranges of $200-300{ }^{\circ} \mathrm{C}$ with an air flow rate ranges of $3.2-5.5 \mathrm{~m} / \mathrm{s}$ for $\geq 1 \mathrm{~min}$. In infrared assisted hot air popping the machine consist of a heating coil which is heated by 1000 watts of 4 ceramic infrared heaters and air velocity provided through heating coil to produce the hot air able to pop the sorghum in the popping vessel in a plastic zip bag the popped and unpopped sorghum samples are collected separately for further studies.

\section{Nutritional analysis}

The raw sorghum subjected to infrared assisted hot air popping. The popped sorghum is collected and it is grounded and sieved by using $1 \mathrm{~mm}$ sieve.

\section{Proximate composition}

As per the standard method of AOAC (2000) the proximate analysis of representative sample of the moisture content, ash, fat, fiber, protein, total carbohydrate and mineral content of popped sorghum samples was identified. The results were expressed as the average product of the value except for the mineral content, and all determinations were made in triplicate.

\section{Total phenolic content}

Folin-ciocalaetu method was used for the determination of phenolic compound (Singleton, Orthofer \& Lamuela-Raventos, 1999). Phenol react with phosphomolybdic acid in folin-ciocalaetu reagent in alkaline medium and produce blue colored complex. TPC expressed in gallic acid equivalents.

\section{Antioxidant activity}

The antioxidant activity of popped sorghum was measured in terms of hydrogen donating or radical scavenging ability using by antioxidant assays method such as DPPH free radical scavenging. 1,1 - Diphenyl 2-picrylhydrazyl (DPPH) is a stable free radical, with 
an unpaired valence electron at one atom of nitrogen bridge (Eklund et al., 2005). It is a common colorimetric reagent that can be kept indefinitely with little decomposition, and neither dimerizes nor reacts with oxygen. Due to its distinguishable color transition from deep -violet to yellow when reduced and color is measured at $517 \mathrm{~nm}$, it is often used for the determination of antioxidant properties in several compounds.

\section{Minerals}

After dry washing of the sample an Atomic Absorption Spectrophotometer (Analyst 300 Perkin Elmer) was used to determine the mineral content of the popped sorghum sample. During the determination of $\mathrm{Ca}$ content, a final concentration of $0.5 \%$ of the lanthanum chloride was used to reduce the phosphate effect (Llopart \& Drago, 2016).

\section{Results and Discussion}

This may be the first study that demonstrates the relevance of evaluating the chemical changes of popped sorghum by infrared assisted hot air popping.

\section{Proximate composition}

Proximate composition and mineral content of popped sorghum by a developed infrared assisted machine are delineated in Table 1 and 2 respectively. Except TPC and antioxidant activity all of them are distributed normally. Ebadi et al., (2005) studied that climate, genotype, soil type, fertilization these factors affect the chemical and nutritional composition. The moisture content of sorghum sample varies from 12.34 to $15.79 \%$ (db). Proximate compositions such as moisture, protein, Fat, crude fibre, ash and total carbohydrate varied from 14.018 to $14.12 \%, 11.12$ to $11.38 \%, 3.01$ to $2.98 \%, 1.38$ to $1.3 \%, 1.44$ to $1.4 \%$ and 68.85 to $68.32 \%$ respectively for the popped sorghum tested. Table 1 showed substantial difference in proximate composition at different popping temperatures of $200^{\circ} \mathrm{C}, 250^{\circ} \mathrm{C}$ and $300^{\circ} \mathrm{C}$. so the popping conditions slightly affected the chemical components but not much. The protein content in raw sorghum varies from 10.00 to $14.00 \%$ and other compositions are ash, fat, crude fiber, total carbohydrate varies from 1.54 to $2.29 \%, 2.84$ to $3.12 \%$, 1.72 to $1.65 \%, 77.11$ to $71.46 \%$ respectively reported by Awadelkareem et al., (2009). The popping process doesn't affect the protein, fat, crude fibre similarly total carbohydrate and ash content reduced slightly after popping. Mishra et al., (2015) reported that that the proximate composition was influenced by variety of the sorghum popped. Zapana et al.,( 2020) stated that the puffing operations facilitate the loss of moisture due to heating quinoa and after treatment, the crude protein was reduced. That's compared to raw sorghum. These findings are accepted with Shaker et al., (1995), who stated that the leaching of soluble nitrogen, minerals and other nutrients into the desired solution could be due to nutrient loss.

\section{Total phenolic content}

TPC content is decreased after popping at higher temperature observed in Table 1. The popping temperature affected the TPC content reported by Moraes et al., (2020) showed a range of 0.184 to $0.32 \mathrm{mg}$ GAE/g. Awadelkareem et al., (2005) reported that phenol compounds are in bound form. Pasha et al, (2015) reported that the TPC ranges from 0.166 to $0.362 \mathrm{mg} \mathrm{GAE} / \mathrm{g}$ in cooked sorghum product such as cookies also and the temperature affected the TPC content. In previous studies Choi et al., (2019) reported that TPC content in the raw sorghum was higher than the level observed in the Table 1. Also the tested samples showed differences, TPC content of $0.18,0.27,0.31 \mathrm{mg} \mathrm{GAE} / \mathrm{g}$ at 
a different temperature of $200^{\circ} \mathrm{C}, 250^{\circ} \mathrm{C}$ and $300^{\circ} \mathrm{C}$ respectively. There is a 45 to $47 \%$ decrease in total phenolic content of puffed brown rice during expansion process reported by Mir et al., (2016). Randhir et al., (2008) stated that phenolic content is heat liable substance and during high temperature processing oxidation and thermal degradation causes the reduction of TPC. Sharma \& Gujral, (2011) stated that in all the cultivars, the total phenolic content (TPC) was lowered by sand roasting and microwave cooking caused a greater decrease in the TPC in microwave cooking (up to $49.6 \%$ ).

Table.1 Proximate composition, TPC and antioxidant activity of popped sorghum

\begin{tabular}{|l|c|c|c|}
\hline Parameters & $\mathbf{2 0 0}^{\circ} \mathbf{C}$ & $\mathbf{2 5 0}^{\circ} \mathbf{C}$ & $\mathbf{3 0 0}^{\circ} \mathbf{C}$ \\
\hline Moisture (\% db) & $14.128 \pm 0.305$ & $14.018 \pm 0.837$ & $14.026 \pm 0.349$ \\
\hline Protein (\%) & $11.38 \pm 0.511$ & $11.16 \pm 0.463$ & $11.12 \pm 0.256$ \\
\hline Fat $(\%)$ & $3.01 \pm 0.200$ & $2.99 \pm 0.228$ & $2.98 \pm 0.240$ \\
\hline Crude fibre (\%) & $1.38 \pm 0.053$ & $1.35 \pm 0.045$ & $1.3 \pm 0.126$ \\
\hline Ash (\%) & $1.44 \pm 0.117$ & $1.414 \pm 0.221$ & $1.4 \pm 0.103$ \\
\hline Total carbohydrate (\%) & $68.85 \pm 0.865$ & $68.46 \pm 1.599$ & $68.32 \pm 1.103$ \\
\hline TPC (mg GAE/g) & $0.31 \pm 0.343$ & $0.27 \pm 0.314$ & $0.18 \pm 0.012$ \\
\hline Antioxidant activity \% & $63.8 \pm 2.842$ & $62.72 \pm 5.859$ & $60.58 \pm 1.430$ \\
\hline
\end{tabular}

Results expressed as mean (triplicate) \pm SD, GAE: Gallic acid equivalents, TPC: total phenolic content, db: dry basis

Table.2 Mineral content of popped sorghum

\begin{tabular}{|l|c|c|c|}
\hline Minerals $(\mathbf{m g} / \mathbf{1 0 0 g})$ & $\mathbf{2 0 0}{ }^{\circ} \mathbf{C}$ & $\mathbf{2 5 0}^{\circ} \mathrm{C}$ & $\mathbf{3 0 0}^{\circ} \mathbf{C}$ \\
\hline $\mathrm{Ca}$ & $15.82 \pm 0.733$ & $15.68 \pm 0.569$ & $15.09 \pm 0.558$ \\
\hline $\mathrm{Fe}$ & $4.8 \pm 0.272$ & $4.74 \pm 0.391$ & $4.01 \pm 0.558$ \\
\hline $\mathrm{P}$ & $278.21 \pm 16.622$ & $268.06 \pm 19.017$ & $259.65 \pm 35.747$ \\
\hline $\mathrm{K}$ & $182.29 \pm 1.668$ & $180.79 \pm 1.491$ & $178.84 \pm 3.222$ \\
\hline $\mathrm{Mg}$ & $117.19 \pm 2.391$ & $116.12 \pm 3.707$ & $111.65 \pm 5.697$ \\
\hline $\mathrm{Na}$ & $82.89 \pm 1.535$ & $79.59 \pm 2.955$ & $73.70 \pm 5.408$ \\
\hline $\mathrm{Zn}$ & $3.57 \pm 0.095$ & $3.46 \pm 0.060$ & $3.42 \pm 0.097$ \\
\hline
\end{tabular}

Results expressed as mean (triplicate) \pm SD

\section{Antioxidant activity}

Antioxidant activity in sorghum has decreased after subjecting to a high temperature was obtained in Table 1. Moraes et al., (2018) reported an antioxidant activity ranges from 66.5 to $92.9 \%$ in raw sorghum moreover the high temperature decreased the antioxidant content compared to the raw sorghum. The popped sorghum has an antioxidant capacity of $63.8 \%, 62.72 \%$ and $60.58 \%$ at a temperature of $200^{\circ} \mathrm{C}, 250^{\circ} \mathrm{C} \& 300^{\circ} \mathrm{C}$ respectively. Pasha et al., (2015) stated that the antioxidant activity in untreated sorghum showed a DPPH content varies from 88.4 to $94.2 \%$. Comparing with previous studies the popped sorghum showed a decreased antioxidant activity in our study. Higher temperature during popping affected the antioxidant activity in popped sorghum. Pal et 
al., (2019) in the same way studied the antioxidant activity on puffed rice which also showed a decreased content of antioxidant activity after puffing (Tasie \& Gebreyes, 2020). Stated that the higher the ash value of the varieties, the greater the mineral content in total.

This study showed a decrease in the TPC content and antioxidant activity during popping and the effect of high temperature on sorghum affected slight quality changes in popped sorghum but not much. Sreerama et al., (2008) reported that in popped beans also showed same as this.

\section{Mineral content}

The mineral composition in popped sorghum treated in three different temperatures $\left(200^{\circ} \mathrm{C}\right.$, $250{ }^{\circ} \mathrm{C}$ and $300^{\circ} \mathrm{C}$ ) is as shown in Table.2. Significant changes were observed in the popping conditions with an increase in temperature. The mineral composition in raw sorghum for $\mathrm{Ca}, \mathrm{Fe}, \mathrm{P}, \mathrm{K}, \mathrm{Mg}, \mathrm{Na}, \mathrm{Zn}$ varies from 22.91 to $33.09 \mathrm{mg} / 100 \mathrm{~g}, 5.54$ to 7.65 $\mathrm{mg} / 100 \mathrm{~g}, 334.46$ to $381.37 \mathrm{mg} / 100 \mathrm{~g}, 230.20$ to $264.53 \mathrm{mg} / 100 \mathrm{~g}, 120.10$ to $137.1 \mathrm{mg} / 100 \mathrm{~g}$, 70.56 to $119.29 \mathrm{mg} / 100 \mathrm{~g}$ and 5.02 to 5.44 $\mathrm{mg} / 100 \mathrm{~g}$ respectively, reported by Afify et al., (2012).

Also reported that decreased mineral content of sorghum after cooking. Anithasri, (2018) reported that popped sorghum has an iron content of $4.09 \mathrm{mg} / 100 \mathrm{~g}$, phosphorus content of $214.19 \mathrm{mg} / 100 \mathrm{~g}$ and also calcium content of $21.52 \mathrm{mg} / 100 \mathrm{~g}$.

The mineral content of sorghum varies be influenced by the variety of sorghum was also stated in this studies. Duodu \& Dowell, (2019) stated that sorghum is known to be a good source of potassium, magnesium, iron and is nearly devoid of sodium. In addition, as a result of process conditions, a decrease in mineral content, in particular in gun puffed quinoa, was observed due to the loss of pericarp reported by Zapana et al., (2020).

This study showed that the chemical composition and nutritional values were influenced by different popping conditions mainly temperature. The nutritional composition such as protein, fat, fiber and ash content in the popped sorghums in different temperature ranges was slightly reduced with an increase in temperature but retained a similar range when compared to raw sorghum. The mineral content of the popped sorghum was slightly reduced after popping. The antioxidant activity and TPC content were affected due to high temperature. After popping the antioxidant activity and TPC content slightly reduced when it compared to raw sorghum. The popping conditions were affected the popping quality. As well this study revealed that the infrared assisted popping provided a safe and efficient popping technology to popping industry.

\section{References}

Afify, A. E. M. M., El-BELTAGI, H. S., Abd El-Salam, S. M., \& Omran, A. A. (2012). Effect of soaking, cooking, germination and fermentation processing on proximate analysis and mineral content of three white sorghum varieties (Sorghum bicolor L. Moench). Notulae Botanicae Horti Agrobotanici Cluj-Napoca, 40(2), 92-98.

Ai, Y., Medic, J., Jiang, H., Wang, D., \& Jane, J. L. (2011). Starch characterization and ethanol production of sorghum. Journal of agricultural and food chemistry, 59(13), 7385-7392.

Awadelkareem, A. M., Muralikrishna, G., El Tinay, A. H., \& Mustafa, A. I. (2009). Characterization of tannin and study of in vitro protein digestibility and mineral profile of Sudanese and Indian sorghum cultivars. Pakistan Journal of Nutrition, 8(4), 469-476. 
Choi, S. C., Kim, J. M., Lee, Y. G., \& Kim, C. (2019). Antioxidant activity and contents of total phenolic compounds and anthocyanins according to grain colour in several varieties of Sorghum bicolor (L.) Moench. Cereal research communications, 47(2), 228-238.

de Morais Cardoso, L., Pinheiro, S. S., Martino, H. S. D., \& Pinheiro-Sant'Ana, H. M. (2017). Sorghum (Sorghum bicolor L.): Nutrients, bioactive compounds, and potential impact on human health. Critical reviews in food science and nutrition, 57(2), 372-390.

Dicko, M. H., Gruppen, H., Traoré, A. S., van Berkel, W. J., \& Voragen, A. G. (2005). Evaluation of the effect of germination on phenolic compounds and antioxidant activities in sorghum varieties. Journal of Agricultural and Food Chemistry, 53(7), 2581-2588.

Dykes, L., \& Rooney, L. W. (2006). Sorghum and millet phenols and antioxidants. Journal of cereal science, 44(3), 236-251.

Ebadi, M. R., Pourreza, J., Jamalian, J., Edriss, M. A., Samie, A. H., \& Mirhadi, S. A. (2005). Amino acid content and availability in low, medium and high tannin sorghum grain for poultry. International Journal of Poultry Science, 4(1), 27-31.

Eklund, P. C., Långvik, O. K., Wärnå, J. P., Salmi, T. O., Willför, S. M., \& Sjöholm, R. E. (2005). Chemical studies on antioxidant mechanisms and free radical scavenging properties of lignans. Organic \& biomolecular chemistry, 3(18), 33363347.

Gaul, J. A., \& Rayas-Duarte, P. (2008). Effect of moisture content and tempering method on the functional and sensory properties of popped sorghum. Cereal chemistry, 85(3), 344-350.

Hebbar, H. U., Vishwanathan, K. H., \& Ramesh, M. N. (2004). Development of combined infrared and hot air dryer for vegetables. Journal of food engineering, 65(4), 557-563.

Hoke, K., Houška, M., Průchová, J., Gabrovská, D., Vaculová, K., \& Paulíčková, I (2007). Optimisation of puffing naked barley. Journal of food engineering, 80(4), 1016-1022.

Kumari, R. I. T. U., Singh, K., Singh, R., Bhatia, N., \& Nain, M. S. (2019). Development of healthy ready-to-eat (RTE) breakfast cereal from popped pearl millet. Indian Journal of Agricultural Sciences, 89(5), 877-81.

Léder, I. (2004). Sorghum and millets. Cultivated plants, primarily as food sources, 1, 66-84.

Llopart, E. E., \& Drago, S. R. (2016). Physicochemical properties of sorghum and technological aptitude for popping. Nutritional changes after popping. $L W T$ Food Science and Technology, 71, 316322.

Makkar, H. P. S. (2003). Effects and fate of tannins in ruminant animals, adaptation to tannins, and strategies to overcome detrimental effects of feeding tannin-rich feeds. Small ruminant research,49(3), 241-256.

Miller, H. E., Rigelhof, F., Marquart, L., Prakash, A., \& Kanter, M. (2000). Wholegrain products and antioxidants. Cereal foods world, 45(2), 59-63.

Miller, H. E., Rigelhof, F., Marquart, L., Prakash, A., \& Kanter, M. (2000). Antioxidant content of whole grain breakfast cereals, fruits and vegetables. Journal of the American College of Nutrition, 19(sup3), 312S319S.

Mir, S. A., Bosco, S. J. D., Shah, M. A., \& Mir, M. M. (2016). Effect of puffing on physical and antioxidant properties of brown rice. Food Chemistry, 191, 139146.

Mishra, G., Joshi, D. C., \& Panda, B. K. (2014). Popping and puffing of cereal grains: a review. Journal of grain processing and storage, 1(2), 34-46.

Mishra, G., Joshi, D. C., Mohapatra, D., \& Babu, V. B. (2015). Varietal influence on 
the microwave popping characteristics of sorghum. Journal of Cereal Science, 65, 19-24.

Mohsenin, N. N. (1986). Physical properties of plant and animal materials (No. 581.1 M64 1986).

Moraes, É. A., de Oliveira, F. C., Queiroz, V. A. V., Schaffert, R. E., Cecon, P. R., Moreira, A. V., ... \& Martino, H. S. (2020). Domestic Processing Effects on Antioxidant Capacity, Total Phenols and Phytate Content of Sorghum. Current Nutrition \& Food Science, 16(4), 501507.

Pardeshi, I. L., \& Chattopadhyay, P. K. (2010). Hot air puffing kinetics for soy-fortified wheat-based ready-to-eat (RTE) snacks. Food and bioprocess technology, 3(3), 415-426.

Pasha, I., Riaz, A., Saeed, M., \& Randhawa, M. A. (2015). Exploring the antioxidant perspective of sorghum and millet. Journal of Food Processing and Preservation, 39(6), 1089-1097.

Randhir, R., Kwon, Y. I., \& Shetty, K. (2008). Effect of thermal processing on phenolics, antioxidant activity and health-relevant functionality of select grain sprouts and seedlings. Innovative Food Science \& Emerging Technologies, 9(3), 355-364.

Raninen, K., Lappi, J., Mykkänen, H., \& Poutanen, K. (2011). Dietary fiber type reflects physiological functionality: comparison of grain fiber, inulin, and polydextrose. Nutrition reviews, 69(1), 921.

Shaker, A. M. H., Taha, F. A., \& Fattah, S. A. (1995). Influence of some processing methods on chemical composition of lentil, faba bean and faba bean dishes. Bull. Natl. Nutr. Inst. Arab Rep. Egypt, 15(2), 46-52.

Shen, S., Huang, R., Li, C., Wu, W., Chen, H., Shi, J., ... \& Ye, X. (2018). Phenolic compositions and antioxidant activities differ significantly among sorghum grains with different applications. Molecules, 23(5), 1203.

Shukla, S., \& Gour, S. (2014). Evaluation of physical, nutritional and popping quality of some maize (Zea mays) varieties. Asian Journal of Dairy \& Food Research.

Singleton, V. L., Orthofer, R., \& LamuelaRaventós, R. M. (1999). [14] Analysis of total phenols and other oxidation substrates and antioxidants by means of folin-ciocalteu reagent. Methods in enzymology, 299, 152-178.

Sreerama, Y. N., Sasikala, V. B., \& Pratape, V. M. (2008). Nutritional implications and flour functionality of popped/expanded horse gram. Food chemistry, 108(3), 891899.

Tasie, M. M., \& Gebreyes, B. G. (2020). Characterization of nutritional, antinutritional, and mineral contents of thirty-five sorghum varieties grown in Ethiopia. International journal of food science, 2020.

Wrigley, C. W., Corke, H., \& Walker, C. E. (2004). Encyclopedia of grain science. Academic.

Zapana, F., de Bruijn, J., Vidal, L., Melín, P., González, M. E., Cabrera, G., ... \& Bórquez, R. (2020). Physical, chemical and nutritional characteristics of puffed quinoa. International Journal of Food Science \& Technology, 55(1), 313-322.

\section{How to cite this article:}

Anjitha, P. K., N. Baskaran, N. Venkatachalapathy and Tito Anand, M. 2021. Nutritional Changes of Sorghum after Popping by A Developed Infrared Assisted Hot Air Popping Machine. Int.J.Curr.Microbiol.App.Sci. 10(01): 3620-3627. doi: https://doi.org/10.20546/ijcmas.2021.1001.427 